\title{
14. Exile as a Feeling \\ of Meaninglessness: Egon Hostovský
}

An entirely different characteristic of the human mind is explored by the well-known Czech Jewish author and émigré Egon Hostovský (b. 1908 in Hronov, Czech Republic, d. 1973 in Montclair, New Jersey). Hostovský went into exile twice. First in 1939 to escape the Nazis; the second time in 1948 to escape the Communists. On both occasions he ended up in the United States, where he lived for thirty years until he died in 1973. His family perished in Hitler's concentration camps.

Hostovský was a very prolific and quite established author of philosophical, social, and psychological novels already before WWII. He chose external exile consciously because of his dedication to literature, which he could pursue in Czechoslovakia under the Communist regime only in an adulterated form. This decision was very brave, but at the same time costly, as he lived in double exilein a culture foreign to his own and, essentially, without readers. His exile thus has a very different character from the inner exile or short-term concentration camp exile described in the studies above.

Hostovský continued to write in Czech in America and published his novels in translation. They are mainly about the lives of exiles in the States. His work, however, is of a universal, philosophical type. He is admired for his humanism and psychological observation. Even though he had connections in diplomatic circles, was befriended by the most prominent Czech writers, as well as writers like Graham Green, and despite having a family that joined him, his life in American exile was torture to him. Yet he insisted on continuing with it. He put it succinctly to A. Liehm in his last interview (1974): “What's the use of language if there's no freedom? 
Who knows, perhaps the very fact of my exile and the irreparable loss of my original roots, of my native land, inspired me to do the kind of work which can only be done in exile." ${ }^{62}$ The predicament of exile is well expressed in the same interview by great Czech author Pavel Kohout: "For people like us, each choice is wrong and ridiculous in its own way. But that's what's typical of the situation in which we've found ourselves or into which we've been thrust." ${ }^{63}$ Liehm comments: "Perhaps this is the biggest and most tragic problem, bigger than exile itself: the writer outside his own country and away from its language, in which he continues to write." ${ }^{64}$

Hostovský's themes are very broad. His concern is human nature, the mind, and the fate of modern man under the pressure of the state and its institutions. If we were to interpret the meaning of exile in his works, we could say that, by and large, exile for Hostovský is banishment and solitude. These experiences, so particularly and painfully known to European Jews, are nevertheless those of twentieth-century man as a whole. That is why Hostovský's novels always have a transcendent quality and make a statement about the human predicament in general.

His heroes are often people who are oppressed by modern society, buried beneath mechanized and meaningless tasks which are invariably put above the interests of the individual. The individual is ultimately crushed by superior forces. Looking for meaning is thus Hostovský's main task. His characters are often lost in the labyrinth of their alienating worlds. The reason for this is partly because they do not see the world as objectively good or bad; their only perspective on it is through their own values. At the same time, they are manipulated by the social systems against which they have no chance of winning and whose motives are base.

Society and its institutions keep man in a frenzy of self-forgetting and maddening activity. People get swept into absurd struggles for

62 A. J. Liehm, "Egon Hostovský: A Last Conversation," Canadian Slavonic Papers 16, no. 4 (Winter 1974): 548.

63 Ibid.: 550.

64 Ibid.: 560 . 
absolute power and in vain try to return to feelings of solidarity with each other. But it is difficult for them to find any meaningful purpose. Exile in Hostovský's work is the hopelessness caused by the individual's feeling that life is meaningless. Oppressive governments and institutions, being policed in various ways, being oppressed by technology, alienation, forced conformity-all contribute to this feeling of meaninglessness.

This state of mind, so common among actual refugees, can be found among intelligent people in modern civilization everywhere. The Jewish refugee is thus emblematic of modern man. Even though Hostovský is only meagerly recognized in his home country, where he was proscribed for decades as an émigré, and in his adopted country America, where he was poorly understood and marginalized, his extensive work contributes to twentieth-century thinking about man's desperate struggle to find the self-knowledge and values that would create a world he could actually truly belong to. Hostovský's writing is clearly a continuation of Kafka's take on the world. Their heroes are people who are attempting to make sense of their solitary existence in an alienating world. The fact that Kafka was not compelled to leave his native country, while political circumstances forced exile upon Hostovský, does not change the fact that the two writers' heroes share a similarity in their deep emotional quality. 